\title{
Identification of Information Source Use Patterns in the Students' Distance Learning Process at the Surabaya University, Indonesia
}

\author{
Mutty Hariyati ${ }^{1 *}$, Dody Purwanto ${ }^{1}$, and Rina Juni Rianty ${ }^{1}$ \\ ${ }^{1}$ Surabaya State University
}

\begin{abstract}
As the digital native generation, students need good information literacy skills. Although information literacy education has been introduced at the Surabaya State University, it has not provided indepth knowledge. This study identifies patterns of information sources used by students and provides an overview of student information literacy skills, such as understanding their information needs and retrieval, especially during the pandemic. The study was conducted with a qualitative approach using interviews to collect data collection. The informants included 14 Surabaya State University students selected through purposive sampling and analysed using Thematic Analysis. The findings indicate that the pattern needs to be improved, from the choosing, the search process, and information sources. Furthermore, universities need to improve digital information literacy programs provided by libraries and facilitate access for students to use them as needed.
\end{abstract}

\section{Introduction}

The pandemic impact in 2020 is still felt in Indonesia education. Furthermore, various efforts were conducted by the government to reduce the spread of Covid-19; these included social distancing, LSSR (Large-Scale Social Restrictions), and implementing health protocols. Also, the government shifted work activity to WFH (Working from Home) and diverted teaching and learning activities to Study from Home (Learning from Home). Several universities and colleges have also implemented remote teaching and learning activities known as online lectures (Adibah et al., 2020:39) [1]. Furthermore, the Education and Culture Ministry has prepared support by developing an Android-based distance learning application. It collaborated with several online learning platforms that students and teachers access. [1]. Other facilities such as social media, YouTube, WhatsApp, Google classroom, Zoom, Kahoot, and Schoology are used as independent learning activities [1].

The primary goal of higher education is to prepare students for their future. Therefore, learning activities are still carried out, though from a distance. However, students face many challenges due to the technological disruption in the economy and knowledge transfer. As a digitally native generation, they need to adapt to lecturers' various teaching

styles and methods quickly. Furthermore, many materials coverage and competencies to be mastered enable students to know various information sources used. They include all library materials and other digital sources that are increasingly and quickly accessible. 
However, the ability to access information sources is a question to be answered by educational institutions.

There is no other choice except to make students literate to identify, analyze, and use information sources based on their needs and applied ethics. Without these skills, they have difficulty in carrying out the learning process. The quality of the student output is a challenge for lecturers and educational institutions. Moreover, literate students recognize and know how to use the information correctly [2]. Information technology needs to develop quickly for many people to access various valid information. Therefore, information literate students become independent learners and interact easily with various information sources.

Similar research has been conducted since the early 1980s and continues to this day [3]. Fabiano [4] found that the student's ability to search for information was diverse. However, most of them could not find adequate information, either online or offline. Furthermore, they do not fully understand the difficulties in searching for information, significantly peerreviewed research articles [5]. Blummer and Kenton [4] conveyed in their book entitled Improving Student Information Search that students' low ability is caused by their lack of knowledge and inability to use digital information sources.

The different studies include Dorasway in Irianti (2014: 36) [6], which examined information use patterns in postgraduate students at P.B. Siddharta College of Arts and Science, India. More than $60 \%$ of respondents use the library every day to read and borrow collections, and $93 \%$ are satisfied with all the services available.

The information sources used in higher education depend on students' needs and motivations. Katz et al. [6] stated that it is a cognitive need based on the motivation to explore, satisfy curiosity and understand and master the environment. The information could be obtained from selected sources, such as academic databases, library collections, and lecturer notes [7]. Moreover, students should have information literacy skills and use the sources provided inside or outside the university [7].

This study examines how Surabaya State University students use information sources provided by faculties, universities, or other online sources. Also, it provides an overview of students' literacy skills and strategies in understanding and finding the information needed during the pandemic. The relationship between information literacy skills and the learning results is one of the analysis aspects. Therefore, this study photographs students' learning experiences in understanding how to search, select, analyze, and use the information based on applied ethics.

\section{Research Methods}

A qualitative method is used to explore an ongoing phenomenon's activity, process, and context and describe and clarify one's experiences [8]. Qualitative methods are used when researchers want to know an ongoing phenomenon's activity, process, and context [9]. It is the most appropriate method to explore how students know and use information sources available offline or online.

The respondents comprised of students in their 4th-8th semesters and were willing to be interviewed. The research criteria were based on the purpose and were conducted using the purposive sampling technique. This technique is used in selecting participants according to the determined criteria based on the study needs.

Interviews were the only data collection technique to investigate a person's views, experiences, and motivations for a phenomenon [10]. Through interviews, researchers uncover rich and complex information [11]. The interviews were divided into informal conversational, guide approach, and standardized open-ended interviews [12]. 
Thematic analysis was used to identify and analyze the phenomenon being studied [13]. The method could be used to analyze qualitative data obtained from in-depth or semistructured interviews [14]. Therefore, it is essential to understand this pattern because it focuses on using information sources during the lecture activities.

\section{Result and Discussion}

The interviews results show the informants' characteristic data of 14 students at the State University of Surabaya. It is listed in the following table.

Table 1. Information Characteristic.

\begin{tabular}{|c|c|c|c|c|}
\hline Num & Initial & Semester & Status & Faculty \\
\hline 1 & FIP 1 & $7^{\text {th }}$ & Students & Faculty of Science Education \\
\hline 2 & FIP 2 & $7^{\text {th }}$ & Students & Faculty of Science Education \\
\hline 3 & FMIPA1 & $7^{\text {th }}$ & Biology Students & Faculty of Math and Science \\
\hline 4 & FMIPA 2 & $7^{\text {th }}$ & Science Students & Faculty of Math and Science \\
\hline 5 & FISH 1 & $7^{\text {th }}$ & $\begin{array}{ll}\text { State } & \text { Administration } \\
& \text { Student } \\
\end{array}$ & $\begin{array}{c}\text { Faculty of Social Sciences and } \\
\text { Law }\end{array}$ \\
\hline 6 & FISH 2 & $7^{\text {th }}$ & Law students & $\begin{array}{c}\text { Faculty of Social Sciences and } \\
\text { Law } \\
\end{array}$ \\
\hline 7 & FBS 1 & $7^{\text {th }}$ & Design Students & Faculty of Language and Art \\
\hline 8 & FBS 2 & $7^{\text {th }}$ & English Students & Faculty of Language and Art \\
\hline 9 & F.T. 1 & $7^{\text {th }}$ & $\begin{array}{c}\text { Information } \\
\text { Engineering Student }\end{array}$ & Faculty of Engineering \\
\hline 10 & F.T. 2 & $7^{\text {th }}$ & $\begin{array}{c}\text { Information } \\
\text { Engineering Student }\end{array}$ & Faculty of Engineering \\
\hline 11 & FIO 1 & $7^{\text {th }}$ & $\begin{array}{c}\text { Health } \quad \text { and } \\
\text { Recreation Education } \\
\text { Students }\end{array}$ & Faculty of Sports Science \\
\hline 12 & FIO 2 & $8^{\text {th }}$ & $\begin{array}{c}\text { Health } \quad \text { and } \\
\text { Recreation Education } \\
\text { Students }\end{array}$ & Faculty of Sports Science \\
\hline
\end{tabular}

Source: processed Researcher's Primary Data, 2021.

Based on Table 1, the participants willing to conduct interviews were dominated by $7^{\text {th }}$ semester students. Each faculty was represented by two students with different majors.

Furthermore, each participant of distance learning had a different story. Some feel the lectures are less effective compared to the offline versions, as stated by the following participants:

"It is good, one could study while relaxing. However, there are obstacles, such as the research section and the internship." (FISH 1)

"The students must look for it, though many institutions do not accept internships during the pandemic." (FISH 1)

A similar story was expressed by a participant from the Faculty of Engineering, that distance lectures were less impressive, as in the following quote:

"In their personal opinion, remotely or online, until now, it still does not feel as

being in college. During the first three semesters yesterday, they felt that offline did 
not exist because of the online. Therefore, getting together with friends, doing assignments together, getting face-to-face learning, and campus organizational activities feel bad at all. They are still studying online for the last three semesters and can only interact via social media, zoom, or g-meet. Their department of informatics engineering adopts online lectures because there are many boot camps or courses from the internet or from other campuses that have implemented online learning. Maybe Indonesian people's background likes socializing; it is not fun when it is still online. Going to the Lab for practicum is just playing or doing research; it is also not possible because the campus prohibits anyone from gathering there. Also, the lab lecturers forbid going to the Lab during the pandemic, although they know that lab assistants go there with key several times. Those majoring in computer science and RPL go online for practicum because they practice coding on a laptop. However, those majoring in networking have to practice with computer hardware, such as cables, routers, modems, servers, and others in the Lab. It is not easy to buy it yourself for an independent practicum or try it out due to the high price. Therefore, they only use simulations via applications on the laptop without directly touching the original hardware. It is also difficult because the informatics engineer is behind the scenes or the technician who holds the tool directly. Then the online lecture process is bad because the implementation of face-to-face online classes depends on the lecturer. Some lecturers have diligently given online classes every time the subject is held. However, other lecturers have never given online classes from the beginning until the end and only give assignments via Google Classroom. Furthermore, some rarely give classes, only one to five online meetings, the rest via Google Classroom. The unclear material explanation forced us to learn everything independently via the internet, ppt material, e-books, or journals from lecturers. Maybe it is normal because most other major students are in trouble, especially when they want to ask, but the lecturer is slow to respond. They are mostly provided with a google classroom from each material, asking questions through that platform but maybe because of the pandemic and online conditions. They think the students' laziness increases, and many are doing and collecting assignments out of deadlines. Many things affect it too; their encouragement is decreased." (F.T. 2)

Different from the previous participants from the other Faculty, Fio stated that distance learning has positive and negative sides, as in the following quote:

"In their opinion, distance learning has both positive and negative impacts. It is negative when they have a course that requires practice, and practicum is constrained because some facilities are only available on campus. The positive value is they explore learning more because they have freedom of time and place to study." (FIO 1)

Students in distance learning face several obstacles during this pandemic, as expressed by the participant from the Faculty of Mathematics and Science:

"For them, most of the obstacles are voice and social media. Usually, when they use their cellphone, they use earphones, and the sound is clear. However, sometimes in the middle of the material, a friend or relative sends a message on W.A., sometimes they respond immediately. Therefore, their mind is splitting, and their focus on listening is reduced. Sometimes the sound is a bit unclear due to the signal effect." (FMIPA 2)

The solution carried out was also conveyed by FMIPA 2 participants when they experienced problems as mentioned earlier:

"Yes, usually when there is an incoming message that is not too important, they respond by saying they are still in college, or sometimes they do not respond. However, when 
important, they automatically respond only via chat, not audio calls or video calls. As for the signal, usually, when it does not slow down, they move to a position where the signal strength is better." (FMIPA 2)

"Yes, sometimes it is a signal, not very often. When they run out of quota, they use a backup package. Therefore, they are prepared to deal with such things." (FMIPA

2)

These results indicate that students are still interested in learning activities directly rather than remotely, which is in line with Nabil et al. (2021: 13). Students are not interested in e-learning because it is less fun than physical classes [Dewaele et al., 2019; Hasan \& Bao, 2020]. Therefore, many scholars have suggested focusing on planning sustainable and attractively designed online curricula [Lee, Lim \& Kim, 2016; Chung \& Cheon, 2020] in Nabil et al., (2021: 13).

The description of information literacy skills and student usage patterns still needs improvement. This is because students still use familiar and easily accessible information sources.

A similar reason was also expressed by a participant from the Faculty of Economics who said that:

"The reason for taking references from Wikipedia and journals is because they are

the simplest in their opinion. However, many online references are complicated,

such as having to log in with an account and use certain codes." (F.E. 2)

Interviews results illustrate that most students use information sources in journals, articles, scientific works, and books. Also, they use materials provided by lecturers to complete various course assignments such as papers, theses, and practical assignments in the form of videos. Some students also took notes on the material during online lectures to review and help them remember.

The participants are good at using information sources but need improvement in searching strategies and selecting sources. Wilson (1999: 261-262) [15] proposed a search process model from empirical research, identifying user judgments, search tactics or moves, and interactive feedback loops. Also, the model identifies the cycle to search for a person interacting with the I.R. system. This system is used to retrieve information relevant to user needs automatically. Spink [12] stated that each search strategy consists of cycles with one or more interactive feedback events.

Moreover, an input may represent a step in the search strategy and may be considered a search tactic to continue the search. Each step consists of user input or system output requests. The value of this I.R. interaction view is based directly on empirical research. Furthermore, the emergence of user judgment, search tactics, and interactive feedback loops link I.R. interactions directly with general information-seeking behaviour. Therefore, user-generated judgments should be based on previous experience in the overall information-seeking activity. Also, the judgments should be based on the tactics and moves derived from the behaviour and used in settings other than interactive I.R. systems.

The knowledge and ability of students' information literacy are seen in the literature review to complete lecture assignments. Moreover, it is seen when faced with how information sources are available on their campus. Some student statements taken from interview excerpts are as follows:

"For reference materials, it usually depends on the direction of the lecturer at first.

But when the reference is from the faculty library, the university does not know until now because usually everything is from the internet and they have never heard of anything from the library... indeed at university the library is open and visitors are limited" (FT2)

"Yes, adjust the task orders. They do not know if the website is from campus; they have heard of it but never used it because most of my majors use those from outside this campus. However, from the outside, it is more complete. Because the 
interactions are different for the searching and the techniques are also mostly like independent practicums as well as self-experiments." (F.T. 2)

A similar statement was also conveyed by FBS 2 participants regarding the information sources on the campus:

"They do not know about literature material because they have never been to a library. Furthermore, for links or the web, I just took the reference from there because Google is familiar. For other information, such as community organization activities, they usually discuss via W.A. or meet once to discuss activities or convey information to the respective students in the department. Sometimes they also have discussions with the student affairs officer." (FBS2)

This is slightly different from the statement expressed by FMIPA 2 participants about the sources of information available at the university, namely:

"Hm... when the library is online, they usually look for references for my thesis at digilib. However, in their opinion, the references are incomplete; sometimes, there are only abstracts and articles, there are no full papers and attachments. Therefore, when they study online, they want to know what the steps are in detail, compared to the steps they use. Sometimes there are several steps in doing the thesis that they do not get full examples of, even from the guidance they are only told to read or look for the reference itself." (FMIPA 2)

Students' knowledge about the availability of information sources, especially by the State University of Surabaya, is still lacking. Some participants prefer literature sources from outside the campus. This is quite unfortunate because students do not recognize the information sources where they receive an education. However, the information obtained from outside supports students to develop themselves further.

Most participants still use lecturers as the primary source of information. This is because they adapt to the tasks given and still feel that the sources provided by the lecturer are more accurate and correct. Moreover, students choose the ease of accessing information sources, such as on Google and Google Scholar. The database of these platforms does not ask for special account access, making it difficult for students to find references. By entering the keywords of the required material into the search field, students access various links displayed by search engines. Furthermore, some participants did not know the information sources provided by the university, both majors and faculties. However, some have used information sources from within the campus.

These findings indicate the need for equitable dissemination of information sources and improved literacy programs. Such programs are provided by libraries, departments, faculties, and universities through digital collections that are more complete and easier to access. As a result, students utilize information sources as needed and become more enthusiastic about online learning.

\section{Conclusion}

This study examines how Surabaya State University students use information sources provided by faculties, universities, and other online sources. Also, it provides an overview of students' literacy skills and strategies in understanding their information needs during the pandemic. The findings indicate that the pattern of using information sources among students still needs to be improved. This includes the strategy of choosing information sources, the search process, and the use. Furthermore, universities need to disseminate information sources and improve the literacy programs provided equitably. These programs are provided by libraries, majors, faculties, and universities through digital collections that are more complete and easier to access. As a result, students utilize information sources as needed and become more enthusiastic about online learning. 


\section{References}

1. Adibah, A., Hidaayatullaah, H.N., Simamora, R.M., Fehabutar, D., Mutakinati, L. The Impact of Covid 19 on Indonesian Education and Its Relation to the Philosophy of "Merdeka Belajar." Studies in Philosophy of Science and Education (SiPoSE), Vol.1, No.1, pp. 38-39, (2020)

2. D. Nicholas, et al., "Where and how early-career researchers find scholarly information," Learned Publishing, Vol.30, No.1, pp. 19-29, (2017)

3. C. Bruce, "Seven faces of information literacy," Adelaide: Auslib Press., (1997)

4. B. Blummer, and J.M Kenton, "Improving Student Information Search: a metacognitive approach," London: Chandos Publishing, (2014)

5. A. Switzer, and S.W Perdue., "A Research and Writing Intervention for Education Graduate Students," Education Libraries, Vol.34, No.1, (2011)

6. P. Irianti, "Pola Penggunaan Sumber Informasi Di Perpustakaan Oleh Pemutaka," Visi Pustaka, Vol. 16, No.1, pp: 35-41, (2014)

7. H. Heriyanto and M. Hariyati, "Students' Information Resources During Their Involvement With Research Projects: Indonesia Setting," Lbr. Philos Pract, (2020)

8. Joh, W. Creswell, "Research Design: Qualitative, Quantitative, and Mixed Method Approaches." Los Angeles: Sage, (2014)

9. H.S Speziale, and D.R. Carpenter, "Qualitative Research in Nursing: Advancing the Humanistic Imperative," Philadelphia: Lippincott Williams \& Wilkins, (2007)

10. P. Gill, K. Stewart, E. Treasure, and B. Chadwick, "Methods of Data Collection in Qualitative Research: Interviews and Focus Groups," British Dental Journal, 204(6), 291-295, (2008)

11. R. Y. Cavana, B. Delahaye, and U. Sekaran, "Applied business research: qualitative and quantitative methods," Brisbane, Wiley, (2001)

12. M. Q. Patton, "Qualitative Evaluation and Research Methods," California: SAGE Publications, (2015)

13. V. Braun, and V, Clark. "Using Thematic Analysis in Psychology," Qualitative Research in Psychology, Vol. 3, No.2, pp.77-101, (2006)

14. H Heriyanto, "Thematic Analysis sebagai Metode Menganalisa Data untuk Penelitian Kualitatif" Anuva, (Nov 2018)

15. T.D, Wilson, "Models in Information Behaviour Research," Journal of Documentation. Vol. 55, No.3, pp..249-270, (1999) 